\title{
Pink Tide: The Struggle of Venezuela and Bolivia for Social Sustainability
}

\author{
Imelda Masni Juniaty Sianipar $^{1}$, Arthur Jefferson Maya ${ }^{2}$ \\ \{imelda.sianipar@uki.ac.id; arthuur.jmaya@uki.ac.id\} \\ Department of International Relations and Center for Social Justice and Global Responsibility \\ (CSJGR)LPPM - Universitas Kristen Indonesia, Jakarta, Indonesia
}

\begin{abstract}
Since Latin America's transition to neoliberalism in the 1980s, the state has been directed to support privatization and implement structural adjustment to integrate the national economy into the global market. The neoliberal model dominated Latin America for a decade, but in the late 1990s, the community support to neoliberal platform declined due to the increase of social inequality and poverty of the middle class, working-class and indigenous population. Resistance starts in Venezuela then spread to Argentina, Brazil, Bolivia, Ecuador and other Latin American countries known as the "Pink Tide". In the pink tide framework, countries are directed to redistribute the state wealth to low-income families so that the sustainability of society can be maintained. Governments implements such kind of policy is categorized as state left.
\end{abstract}

Keywords: Pink tide, Venezuela, Bolivia, Social Sustainability, State Left

\section{Introduction}

Pink tide is a unique phenomenon in Latin America. This term appeared in the New York Times article, 2005 written by a journalist named Larry Rohter, to describe the general election in Uruguay that won the President from the left, and was a sign of a left turn in Latin America. Three-quarters of Latin America's population has been under a leftist government that has succeeded in coming to power since 1998. Rohter writes that the shift in the region is not directed at the red tide but rather at pink. This color reflects moderate socialist ideas in contrast to the red color that connotes communism. Pink tide or gelombang Merah jambu in Bahasaor marearosa in Spanish and ondarosa in Portuguese illustrates the rise of new left governments that succeeded in achieving power in Latin American in the 1990s to 2000s [1].

Politically, Latin America has experienced many shifts. During the 1970s, many Latin American countries were ruled by military regimes [2]. In the 1980s and 1990s, Latin American countries became more democratic and implemented neoliberal policies[3]. Latin American experts called this phenomenon Latin America's right turn. Entering the 21st century, many Latin American countries are controlled by left (or center-left) governments, known as Pink Tide. According to Levitsky and Roberts (2014), Pink Tide refers to political actors who seek to reduce social and economic inequality [4].

Pink Tide has sparked debate among experts. Castañeda [5] and Edward [6] view this phenomenon as a reproduction of the political model of patronage and clientelism that was popular in the 1930-1960s. Sader [7] understand it as a phenomenon characterized by the presence of governments committed to making changes in the political economy by 
eliminating inequality and the practice of exclusion. Spronk and Webber[8]and Veltmeyer [9] are skeptical of the Pink Tide governments. They believe pink tide governments have not been able to break away from neo-liberalism; instead, they co-opt social movements and trade unions to implement a modified neo-liberalism model.

Between 1998 and 2014, there were 23 left governments in 9 Latin American countries (see table 1). Pink Tide started with the election of Hugo Chavez as Venezuelan president in 1998 with the support of the Fifth Republic Movement (MVR) which he founded in 1997. Then in 2000, Ricardo Lagos from the socialist Partido Socialista de Chile party was elected as President of Chile. In 2002, Luis Inacio Lula da Silva was elected as president of Brazil with the support of the Partido dos Trabalhadores Labor Party. Subsequently, in 2003, Nestor Kirchner was elected President of Argentina with the support of the PartidoJusticialista labor party. In 2004, Tabare Vazquez, with the support of Frente Amplia was elected President of Uruguay. In 2005, Evo Morales, with the support of the Movimiento al Socialismo party, won the presidential election in Bolivia.

Table 1. Leftist presidents in South America, 1998 - 2014

\begin{tabular}{|c|c|c|c|}
\hline Year & President & Party & Country \\
\hline 1998 & Hugo Chávez & The Fifth Republic Movement (MVR) & Venezuela \\
\hline \multirow[t]{2}{*}{2000} & Hugo Chávez & The Fifth Republic Movement (MVR) & Venezuela \\
\hline & Ricardo Lagos & PartidoSocialista de Chile (PSCh) & Chile \\
\hline 2002 & Lula da Silva & Partido dos Trabalhadores (PT) & Brasil \\
\hline 2003 & Nestor Kirchner & PartidoJusticialista (PJ) & Argentina \\
\hline 2004 & TabaréVázquez & FrenteAmplia (FA) & Uruguay \\
\hline 2005 & Evo Morales & Movimiento al Socialismo (MAS) & Bolivia \\
\hline \multirow[t]{4}{*}{2006} & Hugo Chávez & United Socialist Party of Venezuela (PSUV) & Venezuela \\
\hline & Lula da Silva & Partido dos Trabalhadores (PT) & Brasil \\
\hline & Michele Bachelet & Socialist Party of Chile (PSCh) & Chile \\
\hline & Rafael Correa & $\begin{array}{c}\text { MovimientoAlianza PAIS - Patria Altiva I } \\
\text { Soberana (PAIS) }\end{array}$ & Equador \\
\hline 2007 & Cristina Kirchner & PartidoJusticialista (PJ) & Argentina \\
\hline 2008 & Fernando Lugo & AlianzaPatrióticapara el Cambio (APC) & Paraguay \\
\hline \multirow[t]{3}{*}{2009} & José PepeMujica & FrenteAmplia (FA) & Uruguay \\
\hline & Rafael Correa & $\begin{array}{c}\text { MovimientoAlianza PAIS - Patria Altiva I } \\
\text { Soberana (PAIS) }\end{array}$ & Equador \\
\hline & Evo Morales & Movimiento al Socialismo (MAS) & Bolivia \\
\hline 2010 & DilmaRoussef & Partido dos Trabalhadores (PT) & Brasil \\
\hline \multirow[t]{2}{*}{2011} & OllantaHumala & Peruvian Nationalist Party (PNP) & Peru \\
\hline & Cristina Kirchner & PartidoJusticialista (PJ) & Argentina \\
\hline 2012 & Hugo Chávez & United Socialist Party of Venezuela (PSUV) & Venezuela \\
\hline 2013 & Rafael Correa & $\begin{array}{c}\text { MovimientoAlianza PAIS - Patria Altiva I } \\
\text { Soberana }\end{array}$ & Equador \\
\hline & NicolásMaduro & United Socialist Party of Venezuela (PSUV) & Venezuela \\
\hline 2014 & Michele Bachelet & Coalition Nueva Mayoria (PSCh) & Chile \\
\hline
\end{tabular}

Furthermore, in 2006, there were five victories obtained by Latin American leftist leaders. Hugo Chavez with the support of the Fifth Republic Movement (MVR) was elected as President of Venezuela, and Luiz Inacio Lula da Silva with the support of the Labor Party Partido dos Trabalhadores was elected as President of Brazil for the second period. Michele Bachelet from the socialist party was elected as the first female President of Chile. Rafael 
Correa with support from Movimiento Alianza PAIS - Patria Altiva I Soberana was elected as President of Ecuador. In 2007, Cristina Kirchner with the support of the Justicialist Party was elected as a president of Argentina. She succeeded her husband, Néstor Kirchner, who had served as president from 2003 to 2007. Cristina became the second female president of Argentina after Isabel Peron.

In 2008, Fernando Lugo with the support of Alianza Patrióticapara el Cambio was elected President of Paraguay. In 2009, Jose Pepe Mujica was elected President of Uruguay replacing Tabare Vazquez while Rafael Correa and Evo Morales were re-elected as President of Ecuador and Bolivia. In 2010, Dilma Rousseff was elected President of Brazil to replace Lula, who had finished his term after serving for two terms. Rousseff became the First Female President in Brazil. In 2011, Ollanta Humalla was elected as President of Peru while Cristina Kirchner was re-elected as president of Argentina. In 2012, Hugo Chavez was re-elected as president of Venezuela, defeating his challenger, Henrique Capriles. But in 2013, Chavez died and elections were held again in 2013 to determine the new president of Venezuela. Nicolas Maduro, who was Vice President Chavez in 2012 and also the former Venezuelan Foreign Minister, competed against Capriles and finally won the general election by gaining as much as 50.6 percent support. Maduro was installed as Venezuelan President on April 19, 2013. In 2014, Rafael Correa was re-elected as president, as was Michele Bachelet of Chile.

The victory of the Latin American left has reawakened the spirit of nationalism and opposed neoliberalism. The painful experience of Latin American countries with the neoliberal model has triggered simultaneous resistance by the Latin American governments against the neoliberal model. On the one hand, the adoption of the neoliberalism model has indeed benefited Latin American countries by increasing investment flows to Latin American countries and increasing trade relations within Latin American countries and with countries in other regions. On the other hand, the adoption of the neoliberal model also hurts Latin American countries. Restrictions on the role of the state in economic and political activities have led to a decline in the welfare of the lower classes of Latin American society.

This study will focus on the struggle of Venezuela and Bolivia to bring the state back in and pressure the leaders to adopt a policy aimed at reducing social and economic inequality. Thus, they can maintain social sustainability. This study uses secondary data collected from scholar research and paper which are published in books, journals, and websites.

\section{Theoretical framework}

Neoliberalism is an international political economy framework that aims to improve the global economy equally. But the situation is different in Latin America. It has a significant impact on social class in Latin America especially on low-income families and results in a regional social movement in Latin America called the pink tide movement. In A Brief History of Neoliberalism, David Harvey defines neoliberalism clearly. It is said that:

"Neoliberalism is in the first instance a theory of political economic practices that proposes that human well-being can best be advanced by liberating individual entrepreneurial freedoms and skills within an institutional framework characterized by strong private property rights, free markets, and free trade. The role of the state is to create and preserve an institutional framework appropriate for such practices. The state has to guarantee, for example, the quality and integrity of money. It must also set up that military, defense, police and legal structures and functions required to secure private property rights and to 
guarantee, by force if need be, the proper functioning of markets. Furthermore, if markets do not exist (in areas such as land, water, education, health care, social security, or environmental pollution) then they must be created, by state action if necessary. But beyond these tasks, the state should not venture. State interventions in markets (once created) must be kept to a bare minimum because, according to the theory, the state cannot possibly possess enough information to second-guess market signals (prices) and because powerful interest groups will inevitably distort and bias state interventions (particularly in democracies) for their own benefit"[11]

Neoliberalism is an understanding that emphasizes individual freedom through freemarket applications. Respect for individual independence through market freedom is a combination of liberalism and the economic traditions of classical liberalism. Neoliberalism is resistance to the state over market management. The market must be left free and independent in managing the economy. This emphasizes that individuals have the right to independence over wealth. Of course, it is contrary to the goal of the state which is to facilitate its people through collective economic policies. However, neoliberalism never emphasizes efforts to eliminate the state, it only reduces the state's function of the market. As Hayek said, state intervention was seen as endangering individual political freedom and markets. According to him, freedom must be free from state pressure, and the most important freedom is economic freedom, where individuals try to be free economically without state intervention[12]. Hayek's argument is certainly based on classical liberalism which emphasizes individual freedom in market affairs.

The neoliberal model was born from Friedrich August von Hayek's thinking. Hayek's book - The Road to Serfdom becomes the neoliberal scripture. In his book, Hayek rejected the existence of a central (government) plan for economic activity. Hayek said that economic planning is a "disaster". Hayek believes that all efforts made to implement the economic planning will lead to various problems that he calls the road of serfdom. If the state is given the power to control it directly, then the state must oppress individual freedom. There are hardly any individual goals whose success is free from state action. Individuals will only become slaves of the state[13].

Milton Friedman, Hayek's student at the University of Chicago, expressed his neoliberal view in a book entitled The Counter-Revolution in Monetary Theory. Friedman believes in extreme individual freedom of choice. Therefore, neoliberal does not question the unequal distribution of income in society. The growth of conglomerates and other forms of large business units is merely seen as a manifestation of individual activities based on freedom of choice and free competition. The social effects caused by economic power on a handful of powerful groups are not questioned by neoliberalism[14].

Harvey placed the idea of neoliberalism on the most fundamental problem, namely the exploitation of source of wealth that should be part of the lower middle class into the hands of the upper classes who have access to production. Likewise, at the country level, exploitation arises from rich countries towards peripheral countries. According to Harvey, the state was involved in this exploitation by protecting capitalist companies that ravaged wealth. Harvey called this neoliberal practice as accumulation by dispossession, namely eliminating collective land ownership rights, privatization of land and marginalizing small farmers, seizing wealth assets by colonial means. In Karl Marx's thinking, this is called primitive accumulation, turning producers into wage laborers. According to Marx, primitive accumulation is an act of crime. 
Harvey's Idea was reinforced by the concept of the international political economy by Thomas Oatley. According to Oatley, the International political economy is the political battle between the winners and losers of the global economic exchange[15]. Oatley stressed his ideas on capitalist competition in the free trade system, the international monetary system, multinational corporations, and economic development. It has increasingly become evident that the Washington consensus agenda practices the capitalist competition which creates more benefits for the upper class than the lower middle class. In other words, the wealth of the periphery countries will be the target of rich countries.

This conceptual framework will be confirmed in the pink tide phenomenon in Latin America, especially from the experiences of Venezuela and Bolivia. Before Latin America countries became a guinea pig for neoliberalism, they adopted the Import Substitution Industrialization (ISI) model. It is a developmental model that dominated Latin America in the 1930s to 1960s. This model emerged as an alternative to overcome the economic downturn due to the declining demand of European countries and the United States for Latin American primary products in the great depression. This model emphasizes the role of the state in economic activity. This idea was introduced by John Maynard Keynes. Keynes argued that market logic did not always lead to macroeconomic stability. The state needs to intervene in regulating the economy to achieve goals such as poverty eradication and job creation.

Several Latin American countries such as Argentina, Brazil, and Mexico experienced success due to this ISI policy. The three countries have succeeded in developing industrial sites that help economic growth. Between 1933 and 1980 the average annual economic growth rate in Brazil reached 6.3 percent and Mexico reached 6.4 percent. This extraordinary economic growth can be compared to the achievements experienced by South Korea and East Taiwan during the Asian Miracle[16]. However, in the late 1960s, the ISI model began experiencing serious problems both in the economic and political sectors. In the economic field, the real problem comes from within the ISI model itself.

There are several causes of the ISI crisis in Latin America. First, the industrialization process using the ISI model is not yet structurally perfect. To produce manufactured goods, local companies must depend on imported machinery from Europe, the United States, and Japan. Second, domestic demand for manufactured products is very limited. The industry is lack of buyers even though the price is very cheap. For example, Brazilian society can only afford a few refrigerators because of the unequal distribution of income; third, the use of technology in the Latin American industry causes many people are unemployed and they cannot afford to buy products produced by local Latin American companies[2].

The economic crisis together with the debt crisis in 1982 did not provide an alternative development model for Latin American countries except the ISI model and replace it with the neoliberal model. According to Gwynne and Kay, two factors cause Latin America's turn right, namely the global factors and the regional factors[3]. At the global level, the package of economic reforms received strong support from international institutions such as the World Bank and the IMF. The institute's technocrats, together with the community and economic advisors throughout Latin America, are actively pushing for reform, especially in the wake of the debt crisis.

The collapse of the Soviet system along with an economic model that emphasized the role of the state and centralized planning also influence the thinking of Latin American governments to consider the neoliberal model. In the minds of the leaders of countries in the Latin American continent, the neoliberal model is very important to modernize the economies of Latin American countries and make them more competitive in the world market. By modernizing, they will easily attract foreign investment from global corporations. This then 
becomes a justification for the argument there is no alternative model other than neoliberal. The last factor that made Latin American leaders interested in implementing the neoliberal model was the success story of East Asian countries such as Taiwan and Singapore, which were able to improve their economies and recover from the 1980s debt crisis after adopting a policy-oriented in exports in the 1960s. Therefore, Latin American leaders consider that a more export-oriented strategy deserves to be emulated by Latin American countries.

At the regional level, there are several historical and comparative factors. In the 1980s, neoliberal policies provided a framework for freeing the Latin American economy from the debt crisis especially when access to outside loans was suddenly limited. In many countries, the adoption of a new paradigm is also a response to the previous economic paradigm, the inward-oriented ISI. The inward-oriented development economic model has failed and has knocked Latin America out of opportunities to be more integrated into the global economy. Neoliberal policies provide a framework for Latin America to increase trade with countries in other regions and increase investment, capital flows from companies and banks to the region.

The adoption of the neoliberalism model has provided some benefits to Latin American countries especially by increasing Foreign Direct Investment (FDI) flows to Latin American countries and trade relations between Latin American countries and countries in other regions. Research conducted by Francisco L. Rivera-Batiz (2000) shows that in 1998, six of the twelve countries receiving the highest foreign direct investment flows in the world came from Latin America. They are the recipients of more than $80 \%$ of the flow of foreign direct investment. Brazil received $\$ 26.437$ billion and Mexico \$ 10.238 billion. Then, followed by Argentina (\$ 5.7 billion), Chile (\$4.8), Venezuela (\$ 3.8 billion) and Colombia (\$3.0 billion). According to Batiz, the main cause of the massive expansion of the foreign direct investment flows into Latin America is the removal of obstacles to foreign companies conducted by the government in the 1980 s to 1990 s [17].

Besides increasing the FDI, the adoption of the neoliberal model also increased trade between Latin American countries and countries in other regions. Latin America's main trading partners are the United States and the European Union. In the 1980s, the United States and the European Union were the main destinations for Latin American products. China is an important partner for Latin American countries, especially for the supply of commodity goods. For Mexico, China is the second important trade partner since 2003. Trade has increased significantly because Latin American countries are implementing tariff reduction policies and strengthening regional economic integration. In the era of the Import Substitution Industrialization model (ISI), Latin American countries imposed very high tariffs on imported goods. In 1980, Brazil set a tariff of $99.4 \%$ for imported manufactured goods, while other Latin American countries applied an average tariff of 50\%. In the 1990s, Latin American countries made drastic tariff reductions of $10 \%$ on average [18].

Although neoliberal provides many benefits for Latin America, the negative effects are numerous. Restrictions on the role of the state in economic and political activities have reduced the welfare of low-income families. In 2010, UNCTAD showed that in the 1980s, with a GDP growth rate of $1.6 \%$ per year, governments in Latin American countries were still able to create jobs at $3.1 \%$. In the early 1990 s, with a growth rate of $2.8 \%$ per year, these governments were only able to create jobs at $2.6 \%$; and in the 2000 s with a GDP rate of $4.4 \%$ per year, the governments were only able to create jobs at $2.8 \%$. The decrease in the number of jobs has led to high unemployment. In the 1980s, the average unemployment in Latin America is $6.2 \%$ per year. In the 1990 s to 2000 s, it increased to $11.1 \%$ per year[19].

The increasing unemployment automatically increases the number of poor in Latin American. According to the Economic Commission for Latin America (ECLAC), the number 
of poor in Latin American has increased drastically. In the 1980s, before neoliberal policies were implemented in Latin American, the number of poor was $40.5 \%$ or around 136 million people. In the 1990s (after neoliberal policies were implemented), the number of poor increased to $48.3 \%$ or around 200 million people. Meanwhile, the number of extreme poor (with the income of $\$ 2$ per day) has increased dramatically from $18.6 \%$ or 62 million people in the 1980 s to $22.5 \%$ or 93 million in the 1990 s [20].

From the description above, it is reasonable if the resistance to the neoliberal model emerges in Latin America. But, beyond the predictions of experts is that the resistance to the neoliberal model takes the same or similar format as the left ideology promoted by the Soviet Union and Eastern Europe in the Cold War era, whereas experts have long assumed that the leftist ideology had demised since the collapse of the Soviet Union and Eastern Europe as left icons[21]. Levitsky and Roberts pointed out that nearly two-thirds of Latin Americans live under leftist governments

\section{Result and discussion}

\subsection{Venezuelan and Bolivian Struggles}

The application of the neoliberal development model in almost Latin American countries is a response to the crisis in the 1970s to 1980s. This model is characterized by the presence of the IMF and the World Bank as actors of neoliberal development in Latin America. The model adopted is based on the Washington Consensus, a development framework that offers justice and politics by placing individuals as important actors in Latin American development. The role of the state is minimized and the free market to manage and develop itself. In practice, there has been massive investment from world capitalist companies such as Exxon, British Petroleum, Royal Dutch, Shell, Mobil Oil, Texaco, Gulf, and Chevron in Latin America.

Unfortunately, the neoliberalism development model does not provide prosperity and justice as promised. The adoption of the Washington Consensus caused economic, political and social crises in most of the Latin American countries including Venezuela and Bolivia. The period of liberalization produced economic uncertainty and political tension. The origins of the Venezuelan crisis had existed since the Peres regime came to power in 1974-1979. Peres was one of the first generations of Latin American neoliberal governments who introduced economic reforms in the 1990s like Salinas in Mexico, Fujimori in Peru and Menem in Argentina. Economic liberalization results in corruption and political instability in Venezuela due to the oligopolistic war in which the supply of one type of goods is controlled by many multinational companies. The practice of political isolation, the role of the media, the failure of the state in formulating regulations, and the decline in real wages have led Venezuela to the political crisis until the 1990s.

Referring to the crisis, a sustainable development model was formulated in 1988-1998, known as the neoliberalism model - a scheme of economic prosperity and political justice that emphasizes free markets. In reality, the neoliberal model does not provide prosperity and justice, on the contrary, it exploits the wealth of the lower-middle class and enriches the upper class or the capitalists. This situation reinforces the suspicion that the crisis occurred because of the adoption of liberalism and neoliberalism models. Venezuela's experience with neoliberalism from 1989 to 1998 has a development dynamics based on good governance. Good governance itself is the jargon of capitalism in controlling Venezuela through the investment of multinational companies such as Exxon, BP, Royal Dutch Shell, Mobil Oil, 
Texaco, Gulf, and Chevron. According to John's research, massive investment has reduced the non-oil products (see table 2) below [22].

Table 2. Growth Trends in the Venezuelan Economy, 1920-2002 (average annual growth, \%)

\begin{tabular}{ccc}
\hline Year & Non-oil GDP & Manufacturing \\
\hline $1920-1930$ & 10,2 & n.a \\
$1930-1940$ & 2,7 & n.a \\
$1940-1950$ & 9,6 & 6,6 \\
$1950-1957$ & 9,1 & 15,0 \\
$1957-1965$ & 3,4 & 8,5 \\
$1965-1980$ & 5,7 & 5,8 \\
$1980-1990$ & $-0,1$ & 4,3 \\
$1990-1998$ & 2,3 & 1,5 \\
$1998-2002$ & $-1,9$ & $-5,0$ \\
\hline
\end{tabular}

Notes: all output series in 1984 bolivares

Source: Baptista (1997)

Since the adoption of the neoliberalism development model 1989-1998 in Venezuela, non-oil products have declined to 2.7 percent. Meanwhile, manufactured products decreased to 4.3 percent in $1980-1990$, and 1.5 percent in 1990-1998, and dropped dramatically to minus 5.0 in 1998-2002. All types of manufacturing production have declined since the adoption of the neoliberalism development model in Venezuela (see table 3) [22]

Table 3.Growth Rates in Venezuelan Manufacturing 1988-1998 (average annual growth in gross output, \%)

\begin{tabular}{lcc}
\hline & Item & Percentages \\
\hline 362 & All manufacturing & $-1,8$ \\
361 & Glass produces & 5,7 \\
351 & Pottery, ceramics & 3,2 \\
311 & Industrial chemicals & 2,8 \\
384 & Food products & 2,4 \\
372 & Transport equipment & 1,8 \\
356 & Non-ferrous products & 1,5 \\
324 & Plastic products & $-0,3$ \\
321 & Footwear & $-0,4$ \\
313 & Textiles & $-1,2$ \\
342 & Beverages & $-2,5$ \\
324 & Printing \& publishing & $-3,2$ \\
369 & Petroleum derivatives & $-3,7$ \\
382 & Non-metallic minerals & $-4,1$ \\
371 & Non-electric machinery & $-4,6$ \\
383 & Iron and steels & $-6,0$ \\
332 & Electrical machinery & $-6,1$ \\
341 & Wood furniture & $-5,4$ \\
352 & Pulp, paper & $-6,1$ \\
381 & Rubber products & $-6,5$ \\
381 & Other chemical products & $-6,6$ \\
323 & Fabricated metal products & $-7,6$ \\
& Leather products & $-7,7$
\end{tabular}




\begin{tabular}{lcc}
322 & Apparel & $-8,4$ \\
390 & Other manufacturing & $-9,0$ \\
314 & Tobacco & $-9,3$ \\
\hline
\end{tabular}

Besides the decline in manufacturing production, there was also a dramatic decline in labor wages. Capitalists practice unfair labor payments in Venezuela. This situation confirms Harvey's argument about accumulation by dispossession in which neoliberalism exploits the wealth of the lower middle class into the hands of capitalists as well as the exploitation of the wealth of peripheral countries to rich countries. Harvey added that the state was involved in this exploitation because it protected the capitalist jargon corporations from extracting the wealth of the lower middle class(see table 4) [22].

Table 4. Net Factor Distribution of National Income in Venezuela 1950-1998

\begin{tabular}{ccc}
\hline year & $\begin{array}{c}\text { Share of wages and salaries in national } \\
\text { income (annual average percent) }\end{array}$ & $\begin{array}{c}\text { Share of corporate profits, dividends, rents } \\
\text { and interest payments in national income } \\
\text { (annual average percent) }\end{array}$ \\
\hline $1950-1960$ & 47 & 53 \\
$1960-1970$ & 46 & 54 \\
$1970-1980$ & 49 & 51 \\
$1980-1988$ & 46 & 54 \\
$1989-1998$ & 36 & 64 \\
\hline
\end{tabular}

The data in Table 4 shows that labor costs and company profits in 1950-1960 were 47\% of workers' wages and 53\% of company profits. In 1960-1970, labor costs were $46 \%$ and company profits were $54 \%$. In 1970-1980, labor wages were $49 \%$ and corporate profits were $51 \%$. In 1980-1988, labor costs were $46 \%$ and company profits were $54 \%$. There have been significant changes since the role of the state was minimized and the neoliberal development model was applied. This can be seen from 1989-1998, laborers' wages are very much different from company profits. The profits of transnational companies reach $64 \%$ of the wealth of the Venezuelan people, while the wages earned by workers are only $36 \%$ of national income.

Besides Venezuela, Bolivia has similar experiences related to the application of neoliberalism to develop the domestic economy. The global capitalist movement based on the Structural Adjustment Program (SAP) has pushed Bolivia for significant economic growth. In general, the involvement of the IMF and the World Bank was able to overcome Bolivia's economic problems. Previously, Bolivia adopted the Import Substitution Industrialization (ISI) development, model. The ISI, which focuses on the pattern of developing a single export economy that makes developing or diversifying other business sectors neglected, forces Bolivia to undertake large-scale imports in unmanaged sectors such as agriculture. In the 1980s the government was forced to borrow from international financial institutions which subsequently affected Bolivia's foreign debt, $\$ 3.8$ billion and was accompanied by inflation around 2,000\% from 1984-1985. The country's Gross Domestic Product (GDP) has dropped dramatically from $\$ 5.9$ billion to $\$ 4.7$ billion in one (1) year.

Debt and inflation ultimately led Bolivia to IMF and World Bank. In 1985, Bolivia received financial assistance from that giant institution which was followed by the policy of regulatory restructuring and direction of free market-based economic policy, privatization, and a floating exchange rate model. SAP is aimed at inviting all foreign investors (FDI) to Bolivia. Bolivia's macroeconomic growth can be saved and change. In a few months, inflation of $2,000 \%$ declined to $9 \%$. 
Nevertheless, economic growth only touches the macroeconomy. The IMF and WB financial aid packages, however, pose complex problems. Starting from the policy of closing mines that are considered no longer produce, so the impact on unemployment as much as 23,000. Besides, 25,000 village teachers lost their jobs, and 10,000 public administration employees laid off. The closure was followed by government policies that abolished subsidies. In 2002, Bolivia's poor population reached $62.7 \%$ and approximately $14.4 \%$ had an income of less than the US \$ 1 per day.

The Washington Consensus is more rescuing the outer package from the economic order, without paying attention to the inequality of the lower classes. FDI reduced Bolivia's inflation from $2,000 \%$ to $9 \%$ but has created an economic gap between the classes that have access to the means of production (capitalist) and the working class (proletariat). The poverty, inequality, and unemployment fell by the lower middle class of Bolivians became the basis for the emergence of local movements in the Bolivian community to stem the movement of the elitist global capitalism.

\subsection{Pink Tide Movement}

Since the end of the ISI model period from 1930 to 1980, Latin America has been a guinea pig or laboratory for neoliberalism, beginning in Chile and Argentina in the 1970s. This capitalism movement spread to almost Latin American countries. This movement coincides with decades of crisis in the 1980s. Latin America is the region that has experienced the most comprehensive neoliberal transformation in the world[7]. Latin American countries experiencing the euphoria of neoliberalism, hastily promoting trade and financial liberalization models, cutting subsidies and privatizing state assets, while companies integrate themselves into parts of the global value chain. The promotion of liberalization continued until the late 1990s. People's support for neoliberalism has decreased due to poverty and social inequality. It started in Venezuela in 1998.

The people then build an alliance to support leaders who are anti-neoliberalism. The antineoliberal platform has succeeded in influencing other American countries such as Brazil and Argentina. This anti-neoliberalism movement is known as the pink tide. The victory of liberalism in the cold war period gave rise to cynicism over socialism in Latin America, so that the global de-idealization by the United States has colored the economic and political transformation with the neoliberal octopus model. It became the only choice of development models in Latin America. The adoption of this model has created unstable growth that depends on foreign direct investment, as well as unemployment increase, informal labor markets, poverty, and inequality.

Thus, the period of neoliberal domination in Latin America did not last long. It was then hit by the onslaught of "pink" masses who were suing the neoliberal model of development which continued to create economic inequality and political injustice. This phenomenon is marked by political transformation through the victory of anti-neoliberal leaders. The alternative model of development adopted by Latin American countries is influenced by a touch of participatory democracy. This popular participation refers to changes that occur among others; prolonged conflict and a struggle out of the crisis; a transition period based on distrust in the modern development model; economic and political transformation; and, a development effort refers to alternative development. This alternative model of development is inseparable from the pink tide phenomenon. It has the same pattern as the nation statism period.

Pink tide is a socialist movement that is considered very phenomenal in the postmodern era. Many experts claim that this movement is not a red left movement, but a collective 
movement that responded to the defeat of the Soviet Union in the cold war and the failure of neoliberalism in bringing prosperity to Latin America. Pontoh said that the Latin American community movement has two fundamental reasons, namely the failure of left-wing communism socialism led by the Soviet Union and economic inequality because of the US neoliberal development model.

The pink tide phenomenon is even more interesting because it questions the principles of the neoliberal free market which has an impact on interdependence in which market control is in the hands of individuals. He also tried to stem the transformation of the political economy based on the US neoliberalism movement because it had no impact on prosperity but instead widened the gap of inequality. Pink Tide also offers a reverse model with neoliberalism about the determination of global markets. Neoliberalism believes that the global structure will determine the domestic development of developing countries, while the pink tide believes that the determination of the structure of the global market is more capitalist in nature which results in the alienation of proletarian and exploitative social classes. This confirms Gilpin's statement in the nature of political economy related to the global political economy, including; the mechanism of the global market in the international economy is interdependent; the political economy problem lies in the government's policy factors regarding economic and political transformation; and global political economy will affect a country's domestic economy.

If neoliberalism offers social welfare and justice through free markets, then the pink tide offers a more flexible model of mediating the capitalist and the working class through economic and social policies based on negotiation procedures. This is a direct involvement between the capital owner and the working class which is facilitated by the state to negotiate wages for workers' welfare. The important thing in the pink tide character regarding negotiation procedures is raising the working class minimum wage. Thus, the role of the state as a representative of the working class is very important in carrying out negotiation procedures.

Since the transition of the Latin American region to neoliberalism, the state has been used to support the privatization of State-Owned Enterprises, restructuring, and implementation of SAP or Washington Consensus, to integrate the national economy into the global market. In contrast to the pink tide, state power is used to nationalize private companies, manage local resources, reduce poverty, and social justice. Some experts such as Leiva, Luiz Carlos Bresser-Pereira and Feliz, said that pink government actively intervened via subsidies and tax exemptions to stimulate particular economic sectors, used development banks to finance domestic firms, took on a greater role in providing infrastructure and other public goods and so on.

In short, the pink tide movement that implements the neo-developmentalist character seeks to direct accumulation towards patterns that are in line with certain views and are always selective about national development goals. Boito Jr. and Berringer called neodevelopmentalism as the developmentalism of the era of neoliberal capitalism [...] the development policy that is possible within the limits of the neoliberal capitalist model. This means that the character of neo-developmentalism cannot be separated from neoliberalism. However, the application of neo-developmentalism is different from the neoliberal model. Where neo-developmentalism is emphasized on the dominant role of the state rather than the market and prioritizing national industrial production for export purposes.

Despite the chaotic national conditions, neo-developmentalism benefited through the rise of China as an economic locomotive that reached the highest level of economic growth. The dominant role of the state is to describe China as one of the countries that have succeeded in 
implementing neo-developmentalism. The pink tide movement practices neodevelopmentalism as one of the characters from several other characters. The dominant role of the state in managing the national economy is seen in the government of Chaves in Venezuela and Morales in Bolivia. This is supported by a strong parliament from both countries. The pink tide movement is more a combination of state and market power in managing the national economy. In applying the pink tide model, Venezuela and Bolivia adopted the character of developmentalism state (neo) which emphasized state actors in formulating social programs by focusing on gas and oil mining. This is an alternative movement in overcoming economic and social problems left by neoliberalism.

The application of neo-developmentalism in Venezuela and Bolivia has led to confusion, as James Petras said

"Latin American development presents us with a rich array of paradoxes, which befuddle the predictions, prescriptions, and commentaries of writers and academics from the right and left. Abrupt changes and shifts in the political correlation of forces are matched by striking structural continuities".

In applying the pink tide model, the results are not always satisfactory because there are still poverty and social inequalities in Venezuela and Bolivia. However, the pink tide left-wing tsunami interpreted as a shift to the left has shown the emergence of major changes in the $21 \mathrm{st}$ century. Borrowing the Chaves's slogan 21st-century socialism. This phenomenon provides a new model for Latin American development, the colors are aimed at the emergence of various the rise of social movements, political parties and populist leaders who are all 21 st-century leftists.

Borrowing Castaneda's framework, Mexico's former foreign minister, who is also a professor at New York University, mentions that the Latin American left is grouped into two characters. First, the Latin American left has a modern, reformist and internationalist character. This first group of Latin American left refers to the ideology of the Soviet Union's communist-socialist party. Therefore, it is grouped as a hard-core left; second, the Latin American left which has the origins of an old tradition of populism that exhibits characters such as nationalists, rhetoric, and closed-mindedness. This second group tries to show the Latin American left through the rise of populism.

In addition to Castañeda, Raul Madrid, who is a professor at the University of Texas at Austin, in the origins of the two left in Latin America, mentioned that in Latin American history, there was never a phenomenon that moved the Latin American left parties to reach power simultaneously. According to Madrid, this is a significant development of the Latin American left. Like Castenada, Madrid groups the Latin American left into two characters. First, the character of the Latin American left is the "liberal left," which adopts a marketoriented development model inherited from the previous government. This is evident in the application of neo-developmentalism in Brazil and Argentina. Market freedom becomes a model of leftist development. This liberal left is usually reflected by the weakness of the left party's power in parliament, thereby reducing anti-market support. Second, the leftist interventionist character, namely the expansion of state intervention on the factors of production and issuing a maximum budget for the interests of the people, such as subsidies to primary and secondary needs. This interventionist left is oriented towards the interests of the lower classes of society so that the social basis of the working class is more emphasized in making state policy. This is manifested in the application of the pink tide model characterized by traditional developmentalism in Venezuela and Bolivia by Chaves and Morales. However, in practice, liberal left and interventionist left have similarities and differences that are vague 
or unpredictable. In this case, to distinguish the two left must be based on the policies of each leader. In line with the thoughts of Castaneda and Madrid, it can be argued that the pink tide movement in Venezuela and Bolivia has the character of a state left.

State left or hard left in Castaneda's terms and interventionist left in Paul Madrid's term is the application of the pink tide model by expanding the role of the state in various aspects of people's lives, such as economic, social, cultural, and political. The results of applying this model are also different. This character can be traced to the nationalization of private companies, subsidies, and the even distribution of power. Nevertheless, the application of the country's left cannot be separated from what Castaneda mentioned in the second left group, namely the rise of populism in Latin America so that the country's left as one of the pink tide characters becomes more phenomenal. It can work well through the policies of the country's leaders, it can also end if its people or followers lose their trust in the populist leader. This is evidenced in Venezuela and Bolivia which adopted the pink tide model characterized by state left in realizing a sustainable leftist order.

The spectrum of the state left policy which is one of the focuses of this research is the direction of Hugo Chavez's policies in Venezuela and Evo Morales in Bolivia which characterizes the interventionist left. The expansion of the role of the state in Chaves and Morales policies towards natural resources in the energy sector has destroyed market-oriented power, oligarchic systems of governance, and neoliberal politicians, who have dominated Latin America. Besides, Chavez's policy has also destroyed the two-party system controlled by neoliberal politicians and multinational corporation investors. Nevertheless, there are differences in behavior, attitudes, and formulation of community-oriented policies, but both come from the same womb and were born in the same cage namely the socialist womb and the populist cage.

The state left character implemented by Chavez is the anti-market policy which covers various sectors of life. Chavez's policies included the nationalization of private companies such as electricity, steel, and telecommunications. He also conducted restrictions and raised taxes for foreign investors, and established various state or state-owned companies such as airlines and telecommunications. In line with Chavez, Morales also carried out a similar policy of taking over private companies such as foreign gas companies and raised taxes and royalties. Anomaly, the two countries have never built a gap and restricted international trade, although at the same time they did not adopt, even agreed to the Washington Consensus as a model of international trade. This is evidenced by the efforts of cooperation between Venezuela and Bolivia with US competitors such as Russia, China, and Iran.

An important aspect of the pink tide image is the perception of a shift towards more independent foreign policy. These shifts included the establishment of a US war on terror, about relations with $\mathrm{Cuba}$, and in general the adoption of more explicit anti-imperialist discourse. It also includes positions on the globalization of free trade, Latin American economic integration, social welfare, and proclamations regarding alternative political economies.

\section{Conclusions}

The global capitalist movement that made Latin America, especially Venezuela and Bolivia as a guinea pig or laboratory of neoliberalism, had a significant impact on the economic growth of both countries. However, economic growth is more profitable for the capitalists than the working class and local communities. Hence, neoliberal development based on the Washington consensus is seen as an elitist movement of individual capital 
owners who pursue the added value in the accumulation of production in Venezuela and Bolivia with the character of exploiting labor and natural resources. The negative impact caused by the neoliberal implementation is a large gap between the class of foreign investors and the class of local people as workers. Since the adoption of the neo-liberalism development model 1989-1998 in Venezuela, non-oil products have declined by 2.7 percent. Whereas manufactured products decreased by 4.3 percent in 1980-1990, and 1.5 percent in 1990-1998, and dropped dramatically to minus 5.0 in 1998-2002. This happened also in Bolivia, where there was a policy of closing mines which were considered to be no longer producing, thus impacting to 23,000 unemployment. 25,000 teachers lost their jobs, and 10,000 public administration employees were laid off. Also, the application of neoliberal had an impact on the elimination of subsidies for the poor. It was recorded that in 2002 Bolivia's poor were $62.7 \%$ and there were approximately $14.4 \%$ who had income, less than $\$ 1$ per day.

The impact of the neoliberal movement resulted in the social movements of the local people of Venezuela and Bolivia, which are referred to as the pink tide movement. This social movement is mushrooming to all Latin American countries to replace the neoliberal model with populism as an alternative model of development. Pink Tide is marked by the appearance of Chaves in Venezuela and Morales in Bolivia. This wave of resistance to contain neoliberal octopus power is based on a state-centered development model. The developmentalism state model is a people-oriented development characterized by the nationalization of private companies, the provision of subsidies to the poor, the empowerment of domestic corporations, social welfare, and collectivity. This developmentalism model has an impact on the leftist social order.

\section{References}

[1] L. Rohter, "With New Chief, Uruguay Veers Left, in a Latin Pattern.” 2005.

[2] T. E. Skidmore and P. H. Smith, Modern Latin America: Fifth Edition. 2005.

[3] C. Gwynne, Robert R; Kay, Latin America Transformed: Globalization and Modernity, Second. London: The John Hopkins University Press, 2004.

[4] S. Levitsky and K. M. Roberts, "The Resurgence of the Left.” p. 430, 2011.

[5] J. G. Castaneda, "Latin America ' s Left Turn," vol. 85, no. 3, pp. 28-43, 2012.

[6] S. Edwards, Left Behind: Latin America and The False Promise of Populism. Chicago: University of Chicago Press, 2010.

[7] E. Sader, The New Mole: Paths of The Latin America Left. London: Verso, 2011.

[8] J. R. Spronk, S; Webber, Crisis, and Contradiction: Marxist Perspectives on Latin America in the Global Political Economy. Leiden: Brill, 2014.

[9] H. Veltmeyer, "The Political Economy of Natural Resources Extraction: A New Model or Extractive Imperialism ?,” Can. J. Dev. Stud., vol. 34, no. 1, pp. 79-95, 2013.

[10] G. F. Pimenta and P. C. V. M. Arantes, "Rethinking Integration in Latin America: The " Pink Tide " and the Post- Neoliberal Regionalism," FLACSO-ISA Jt. Int. Conf., pp. 120, 2014.

[11] D. Harvey, "HarveyNeoliberalism," 2017.

[12] J. M. Moreira, Hayek, vol. 1, no. 2. 2018.

[13] F. A. Hayek, The Road to Serfdom. London: Routledge Classics, 1944.

[14] B. Setiawan, Menggugat Globalisasi. Jakarta: INFID, 2001.

[15] "Oatley, Thomas." pp. 1-426, 2013.

[16] A. S. Filho, "The Political Economy of Neoliberalism in Latin America," in Neoliberalism: A Critical Reader, D. Filho, Alfredo Saad; Johnston, Ed. London: Pluto 
Press, 2005.

[17] F. L. R. Batiz, "Foreign Direct Investment in Latin America: Current Trends and Future Prospects," New York, 2000.

[18] M. Sotomayor, "Latin America's Trade Performance in The New Millenium," in The 21st Century Economics: A Reference Handbook, Sage Publications, 2010.

[19] UNCTAD, "UNCTAD." UNCTAD, 2010.

[20] ECLAC, "ECLAC." 2008.

[21] N. I. Subono, "Amerika Latin bergerak ke 'Kiri?'" 15 January 2007.

[22] J. Dijon, "Crisis States Programme The Political Economy of Economic Liberalisation in Venezuela," World, no. 46, 2004. 